\title{
Nunavut youth saturated in the realities of suicide
}

$\mathrm{W}$

hen her parents' drinking, her brother's beatings and a close friend's suicide got too much for 17-year-old Carol,* she did what hundreds of young Inuit across Nunavut have done since the territory was created. She formulated a plan to kill herself.

Carol intended to go home, during the day, when she knew she'd be alone in the house. She had ready access to ropes and electrical wiring.

"I was thinking to actually just hang myself," the petite, pretty young woman said in an interview with $C M A J$. She spoke early in 2013, just three weeks after she made her suicide plan. "I'd probably do it in my room, or in the bathroom, or in the closet."

A family friend had killed herself that way. It seemed like a method Carol could also use to end her pain.

"I was going through so much crap with my family — I was just telling myself, 'I've had enough'."

But then Carol thought about leaving her family forever, and her friends. She picked up the phone and called one of them.

"I said 'Yo - I need to talk'," she remembers.

After the conversation, she left the house, crying. Away from the ropes and the wires. Away from the violence.

Since Nunavut was created in 1999 , close to 400 Inuit have killed themselves, according to data that researcher Jack Hicks collected from the files of coroners in Nunavut and the Northwest Territories for his upcoming PhD dissertation for the University of Greenland, in Nuuk. The majority, 305 as of the end of May 2013, were aged 10 to 29. Overall, the incidence of suicide among Inuit in Nunavut is 10 times that of the Canadian population.

Sexual and physical abuse of children, depression, substance abuse, and impulsiveness and aggressiveness were all major factors in the lives of 120 Inuit who committed suicide between 2003 and 2006, as documented in the June 5 study, Qaujivallianiq Inuusiri-

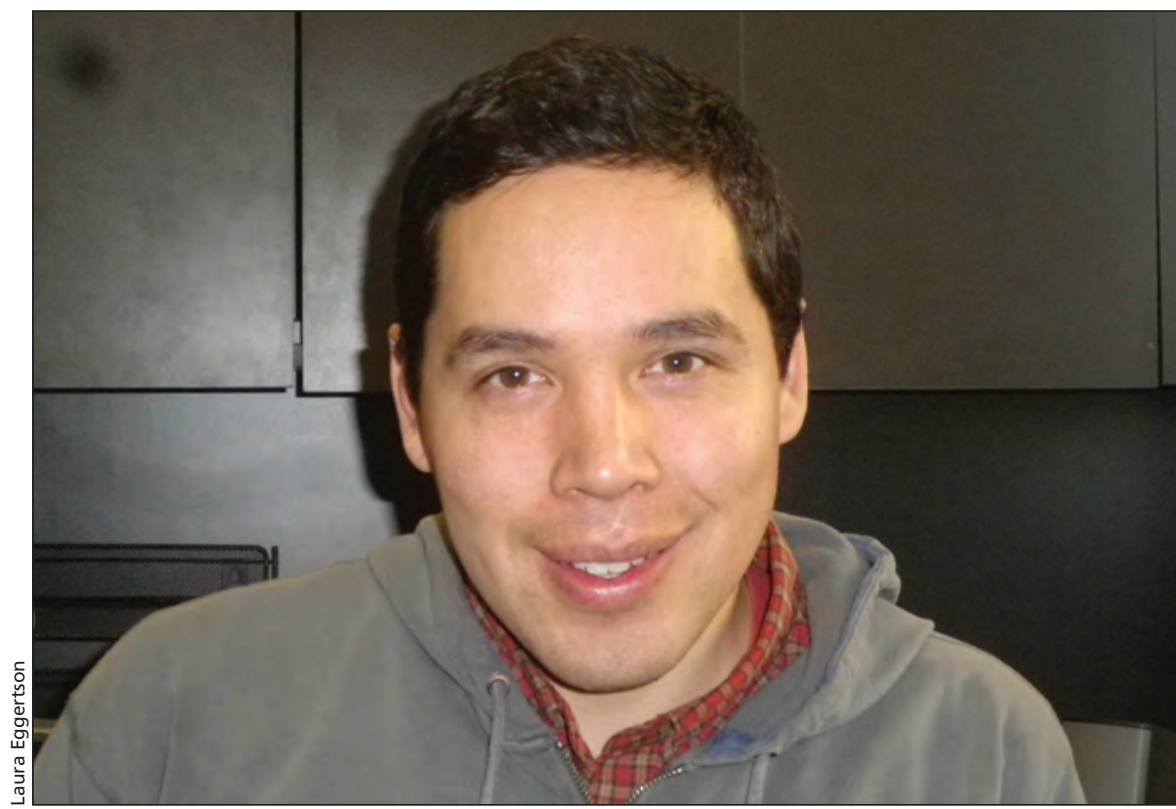

Natan Obed, a director at Nunavut Tunngavit Inc., was instrumental in creating the territory's Suicide Prevention Strategy and Action Plan, which he hopes will be implemented.

jauvalauqtunik, Learning from Lives that Have Been Lived.

Although the Government of Nunavut does not track attempted suicides, Royal Canadian Mounted Police (RCMP) calls to respond to people expressing suicidal intent or attempting to kill themselves total more than 1000 per year, says Natan Obed, director of the Department of Social and Cultural Development at Nunavut Tunngavit Inc. Nunavut Tunngavik is the organization administering Inuit responsibilities under the Nunavut Land Claims Agreement.

The sheer number of suicides and attempted suicides in the territory mean children in Nunavut grow up in a world saturated with the knowledge of how suicide happens, says Obed, the father of two young boys.

"What this means for a person who lives in the territory, a person who grows up in Nunavut, is that you know somebody who died by suicide. You probably have a family member who died by suicide. You have probably talked to somebody who is threatening to attempt suicide. You probably have been in close proximity to a death, whether it is find- ing a body, or helping your friend who has lost a loved one grieve," Obed says.

Moreover, because of Nunavut's sparse population and the connected nature of its families, young people have heard and participated in discussions about the means people choose to kill themselves: by hanging, shooting or overdosing.

The experience in Nunavut corresponds to the findings in a study published in $C M A J$ that concluded exposure to suicide among adolescents predicts suicidal ideation and attempts - the "contagion" effect (www.cmaj.ca/lookup /doi/10.1503/cmaj.130678).

"It's not like living in southern Canada," says Obed, who has lived in Iqaluit, Nunavut and other Inuit communities outside the territory. "Here, it's an on-going sadness that people live with, of all the potential that's been lost, and all the love that they've had for people that somehow didn't translate into people choosing to live and to be part of their communities."

Obed wants a different future for his sons - and for all the Carols in the territory. He was instrumental in creating 
the Nunavut Suicide Prevention Strategy and its subsequent Action Plan, along with Hicks, Steve McVarnock, the former RCMP chief superintendent in Iqaluit, officials with the territory's Department of Health and Social Services, and members of the Embrace Life Council. The strategy was tabled in the legislature in October 2010, and the plan launched in September 2011.

It's too soon to say yet whether the Government of Nunavut will meet its responsibilities in rolling out measures contained in the Action Plan, which sets out timelines that expire Mar. 31, 2014. There are troubling signs that all is not on course. Nonetheless, some prevention measures are paying off for some youth.

One such informal prevention program is a youth drop-in centre that the City of Iqaluit runs on the site of the former Arctic Winter Games. Counsellors greet the 30-40 youth who arrive daily, after school and on the weekends. They feed them, since many have scant food at home. They talk with them and involve them in volunteer activities in the community. Most importantly, they listen.

By the time she talked to CMAJ about her suicide plan, Carol was feeling stronger. She had talked to a mentor at the drop-in centre. She had moved out - although she hadn't told her parents yet. Apparently, they didn't notice she had left home.

She volunteers at community events. She dreams of going to college.

And she has her own ideas about what Nunavut needs to prevent suicides: a team approach to prevention that involves peer-to-peer counselling, and the ability to talk about suicides in schools as they occur. Currently, the discussion of a death is often limited to an announcement over the public-address system and two minutes of silence.
"We need more role models, and a lot of good parenting skills," Carol says. "Also, we need people to trust." - Laura Eggertson, Iqaluit, Nunavut

* CMAJ has used a pseudonym to protect the identity of this minor.

CMAJ 2013. DOI:10.1503/cmaj.109-4519

Editor's notes: This is the second of a four-part series on suicide in Nunavut, Canada at cmaj.ca. See "First psychological autopsy of Nunavut Inuit shows high rates of childhood abuse, depression."

Laura Eggertson received a 2012 Michener-Deacon Fellowship for Investigative Journalism, which supported her travel and the research into this series of articles about suicide by Inuit and First Nations youth.

\section{Patent ruling expands access to genetic tests and treatments}

$\mathrm{T}$ he United States Supreme Court has stripped away three decades of patent protection for human genes in a decision likely to mean broadly cheaper genetic testing and, possibly, accelerated discoveries.

Affirming that no one can corner the market on nature, the ruling promises to bring an expensive set of tests for breast and ovarian cancer within reach for many more high-risk women.

Mere hours after the justices ruled last week, one company announced it would conduct those tests for US\$950, down from the $\$ 3000-\$ 4000$ that it commonly cost when Utah-based Myriad Genetics had exclusive rights to the genes.

The decision opens important areas of research to companies that have been frozen out by patents covering roughly $20 \%$ of human genes, which has raised hope for scientific advances. But there are concerns, too, that the loss of patent protection could make the payoff for pioneering researchers potentially less lucrative and thus inhibit discovery.

On balance, the medical establishment and the government have welcomed the outcome. And the biotechnology industry was heartened by the

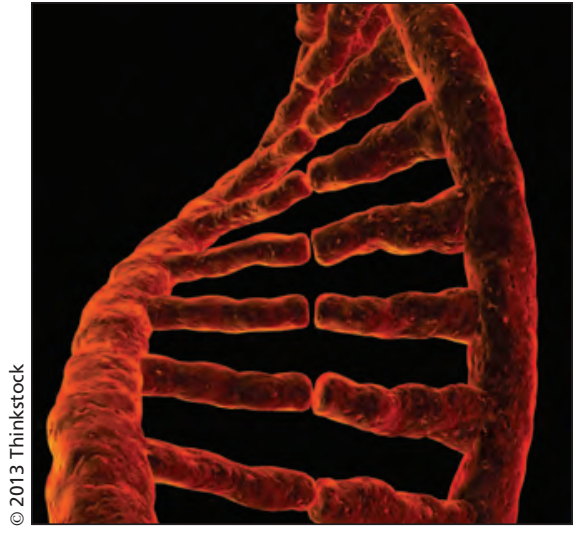

The court decision opens significant areas of research frozen out by patents covering roughly $20 \%$ of human genes.

court's decision to uphold patents on synthetic DNA even though it invalidated rights to natural human genes.

"The decision represents a victory for all those eagerly awaiting more individualized, gene-based approaches to medical care," said Dr. Francis Collins, director of the National Institutes of Health and a geneticist.

"Such approaches form the cornerstone of the rapidly emerging field of personalized medicine, in which diagnostic, therapeutic and preventive strategies can be tailored to each person's unique genetic makeup."

The ruling was the first of a pair that promise to shape the accessibility of medicine. The court recently ruled that "pay to delay" arrangements in the drug industry may be illegal and can be challenged by the government.

Under such arrangements, usually struck when the outcome of a patent lawsuit would be in doubt, a drug company pays a hefty sum to a generic competitor to delay its marketing of a cheap equivalent, typically for a few years. The government says such deals can delay the availability of affordable drugs.

The ruling on gene patents was unanimous, unusual for an ideologically divided court. At issue were the BRCA1 and BRCA2 genes. Mutations in either one greatly increase the risk of breast cancer and, to a lesser but still significant extent, ovarian cancer. When it comes to the building blocks of life, the court affirmed, anyone can play. - Cal Woodward, Washington DC

A longer version of this article is available at cmaj.ca

CMAJ 2013. DOI:10.1503/cmaj.109-4531 